\title{
The Longitudinal Associations of Sound Financial Management Behaviors and Marital Quality
}

Jeffrey P. Dew

Brigham Young University - Provo, jeff_dew@byu.edu

Follow this and additional works at: https://scholarsarchive.byu.edu/facpub

Part of the Other Social and Behavioral Sciences Commons

\section{Original Publication Citation}

Dew, J. P., Barham, C.t, \& Hill, E. J. (2020). The longitudinal associations of sound financial management behaviors and marital quality. Journal of Family and Economic Issues.

\section{BYU ScholarsArchive Citation}

Dew, Jeffrey P., "The Longitudinal Associations of Sound Financial Management Behaviors and Marital Quality" (2020). Faculty Publications. 4545.

https://scholarsarchive.byu.edu/facpub/4545

This Peer-Reviewed Article is brought to you for free and open access by BYU ScholarsArchive. It has been accepted for inclusion in Faculty Publications by an authorized administrator of BYU ScholarsArchive. For more information, please contact ellen_amatangelo@byu.edu. 


\title{
The Longitudinal Associations of Sound Financial Management Behaviors and Marital Quality
}

\author{
Jeffrey Dew ${ }^{1} \cdot$ Connor Barham $^{1} \cdot$ E. Jeffrey Hill ${ }^{1}$
}

๑) Springer Science+Business Media, LLC, part of Springer Nature 2020

\begin{abstract}
We investigated the association between sound financial management behaviors and marital quality, particularly the direction of the association and a potential mediator. To do this, we used three waves of longitudinal dyadic data that spanned three years from 279 married couples living in a large northwestern city and a longitudinal path analysis that incorporated the Actor-Partner Interdependence Model (Kenny et al. Dyadic data analysis. Guilford, New York City, 2006). Marital satisfaction at T1 was positively associated with sound financial management behavior for husbands; we only found actor effects, though. Wives' T2 reports of sound financial management behavior were directly and negatively associated with their own reports of marital conflict at T3. Husbands' T2 reports of sound financial management behavior was negatively associated with $\mathrm{T} 3$ economic pressure, which was positively associated with marital conflict. The indirect association was not statistically significant, however.
\end{abstract}

Keywords Dyadic data $\cdot$ Economic pressure $\cdot$ Financial management behaviors $\cdot$ Longitudinal analyses $\cdot$ Marital quality

Although scholars have been examining behaviors that contribute to marital quality for decades (e.g., Glenn 1990), one behavior, sound financial management, has been relatively understudied (Dew and Xiao 2013). Xiao (2016) defined sound financial management behaviors as those behaviors that will help individuals and families "to achieve financial goals and enhance financial wellbeing" (p. 3). We use Xiao's definition for the present study. And although many studies have examined other financial issues vis-à-vis relationship quality (e.g., see Dew 2016 for a review), most have focused on negative financial events (e.g., Conger and Elder 1994) or proxies of sound financial management behaviors such as asset/debt levels or individuals' feelings about their spouses' spending habits (Britt et al. 2017; Gudmunson et al. 2007). That is, not many studies have measured financial

Jeffrey Dew

jeff_dew@byu.edu

Connor Barham

Connor.barham@gmail.com

E. Jeffrey Hill

Jeff_hill@byu.edu

1 School of Family Life, Brigham Young University, 2101 JFSB, Provo, UT 84602, USA management behaviors, per se, and assessed their value as marital quality predictors.

Despite the lack of research, a more complete understanding of the association between sound financial management behaviors and marital quality would be important for many reasons. First, sound financial management is a skill that is taught across many different social contexts (e.g., through state extension, in religious and employment settings, etc.). Thus, if there is an indirect effect from financial education, to sound financial management, to marital quality, this would be important for the public and policy makers to know. Second, such an analysis would promote scholarship. For example, most studies that have examined the association between sound financial management behavior and marital quality have used cross sectional data. Without longitudinal data, however, we cannot answer questions about the direction of the relationship. That is, although sound financial management behavior might indeed relate to higher-quality marriages, it may instead be the case that higher-quality marriage may encourage sound financial management behaviors. Finally, a study of the association between sound financial management behavior and marital quality might help inform those practitioners who help families. Most marriage and family therapists do not receive much training dealing with financial issues as a presenting 
problem (Stanley and Einhorn 2007). Further, a new area of practice, financial therapy, promotes addressing couples' financial and marital issues simultaneously (Archuleta and Grable 2011). Thus, this study could contribute to practitioners' knowledge base and, by untangling the direction of the association, possibly suggest courses of treatment.

In this study, we addressed the gaps in the literature using dyadic longitudinal data to test the direction of the association between sound financial management behavior and marital quality ( $n=279$ couples) over the course of three years. We also tested a potential mediator of one direction of the associations. Our study is strong in that we had dyadic longitudinal data (uncommon in this area), are able to test the direction of the association, and had multi-item scales to measure the constructs. It is uncommon to have a data set with multi-item scales of both financial management behaviors and marital quality. Further, our analysis is robust in that we controlled for previous levels of the outcome variables in the model.

\section{Literature Review}

\section{Sound Financial Management Behavior}

We take our definition of sound financial management behavior from the fields of financial advising and financial counseling. Although these two fields focus on different clienteles (higher-net-worth individuals and low-to-moderate-income households, respectively), both fields share a definition of sound financial management behaviors (Dew et al. 2020). Within those fields, sound financial management behaviors are those behaviors that will help individuals and families to have and maintain greater financial stability, avoid feelings of economic pressure, and enable them to attain their financial goals (Xiao 2016). Examples of financial management behaviors typically listed as "sound" in these fields include spending less than the household earns, paying off and avoiding consumer debt, establishing and maintaining an emergency savings fund, and investing for retirement (Hilgert et al. 2003; O'Neill et al. 2005).

We recognize that this definition, particularly the term "sound," might seem narrow and based on White middleclass norms. However, studies have shown that lower-income households practice sound financial management behavior (Hogarth and Anguelov 2003) and that these behaviors benefit them. For example, sound financial management behavior was associated with low-income households strengthening their financial situation over time (O'Neill et al. 2005). Further, low-income households that practiced sound financial management behavior reported fewer negative financial events over time (Rothwell and Han 2010), even after being matched based on income, education, etc. with those who did not manage their money. Regarding race, the results of a qualitative study of African American long-term married couples suggested that controlling spending, budgeting, and especially working together jointly on financial issues were important ways to strengthen marriage (Dew et al. 2017). Furthermore, Asian families were more likely to have adequate emergency savings than any other race/ethnic group (Hong and Kao 1997).Thus, we submit that our definition of sound financial management behaviors are not necessarily based on class or race norms.

A few studies have focused on the association between financial management behaviors, per se, and marital quality. For example, Dew and Xiao (2013) found that sound financial management behaviors were positively associated with participants' relationship happiness. Zimmerman and Roberts (2012) found that increased sound financial management behaviors and enhanced marital satisfaction were correlated for couples taking financial education course. Furthermore, in a qualitative, strengths-based assessment of long-term married couples, participants stated that living within their means and avoiding debt were behaviors that had contributed to the quality of their marriage (Skogrand et al. 2011). These studies of the association between sound financial management behaviors and marital quality have assumed that behaviors predict quality (e.g., Zimmerman and Roberts 2012), even when using cross sectional data (Dew and Xiao 2013). One of the main purposes of the present study is to test that association using longitudinal data.

\section{The Association Between Sound Financial Management and Marital Quality}

We examined the associations between sound financial management behaviors and marital quality using a conceptual model we created (Fig. 1). In this model we suggest that Time 1 (T1) marital quality is associated with Time 2 (T2) sound financial management behavior. T2 sound financial management is then indirectly associated with Time 3 (T3) marital quality through the mechanism of economic pressure. Our model combines insights drawn from Becker's (1981) economic theory on marriage, the financial expectations and family formation theory (Gibson-Davis 2009), and the family stress model of economic pressure and marital distress (hereafter called the family stress model; Conger and Elder 1994). Below we discuss the details of these theories and how they contribute to our model.

\section{Economic Perspectives on Marriage}

Although sound financial management behaviors may longitudinally predict marital quality, Becker's (1981) economic theory on marriage suggests that this association may also move in the opposite direction. Becker asserted that 


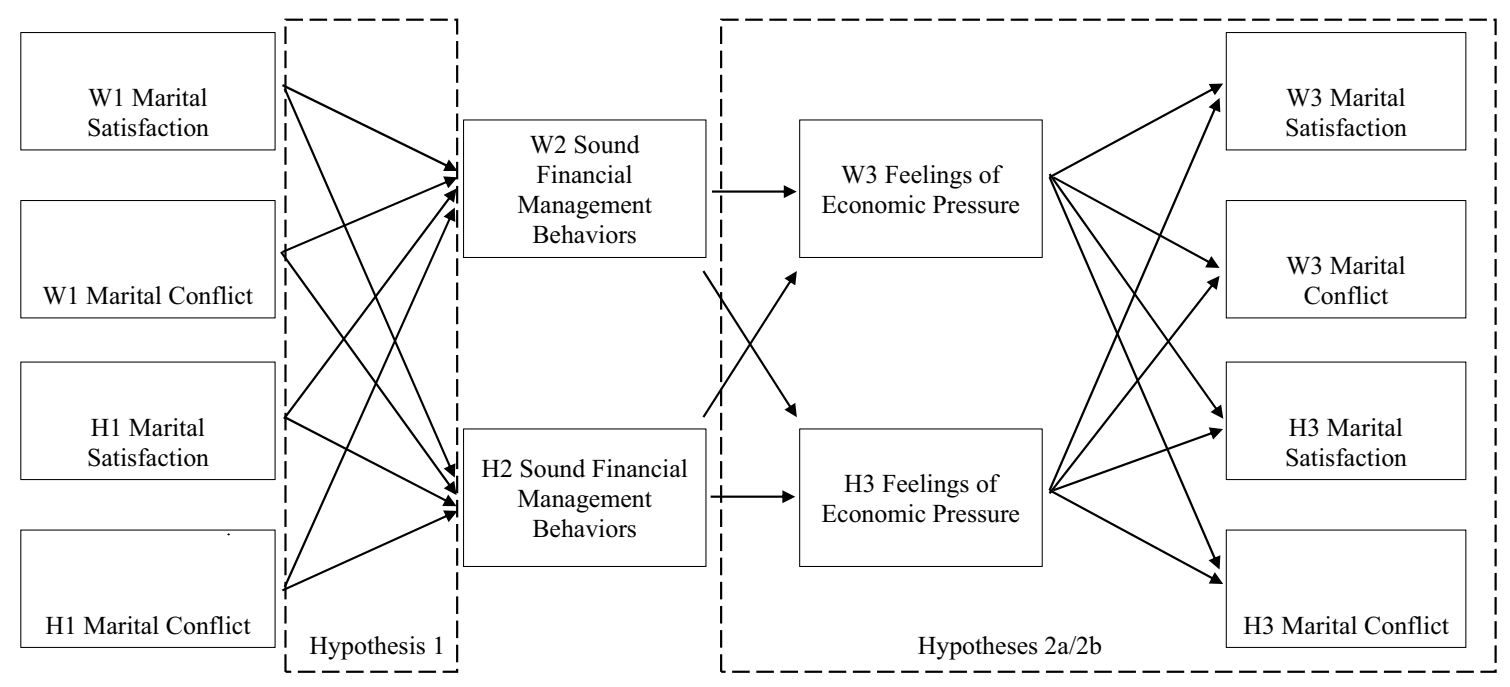

Fig. 1 Conceptual Model of the Associations between Relationship Quality and Sound Financial Management. Hypothesis 3=Partner effects from wives' sound financial management behaviors will be stronger than from husbands' sound financial management behav- iors. Note T2 sound financial management behaviors regressed on T1 sound financial management behaviors, T3 feelings of economic pressure regressed on T2 levels, and T3 marital satisfaction/marital conflict regressed on $\mathrm{T} 2$ levels (not shown) marriage is a calculated individual choice. That is, when individuals feel that the cost-benefit consideration for marrying outweighs the cost-benefit consideration of being single, they will seek to marry. Likewise, if an individual feels that the cost-benefit consideration of leaving a marriage outweighs the cost-benefit of staying, then they would file for a divorce.

A fundamental insight from Becker's (1981) theory, for our purposes, is that those who experience greater happiness or benefits in their marriage will be more likely to invest in that relationship than those who experience less happiness or fewer benefits. That is, those who have more to lose by a divorce will be more likely to invest in the relationship. This will help encourage the marriage to stay intact.

We assert that sound financial management behaviors constitute an investment in one's marriage and that happier couples will be more likely to make these investments. Many sound financial management behaviors (such as saving and avoiding debt) require forgoing individual present pleasure for future financial, family, and/or relationship gains (Jenkins et al. 2002). Individuals may accrue long-term personal or relationship benefits (e.g., spousal congruence in financial matters or spousal gratitude) by engaging in sound financial management behaviors.

Empirical studies support the idea that happier couples will be more likely to financially invest in their relationship (or that unhappy couples begin to divest from their marriage). One study suggested that couples begin to spend down wealth a few years before a divorce (Zagorsky 2005), while another found that couples nearing divorce held less wealth than stable couples unless the spouses had the same income (Finke and Pierce 2006). This behavior is understandable if spouses anticipate the divorce and feel that they will not be able to fully enjoy their assets in the event of a divorce settlement. Furthermore, couples who felt that their relationships were more stable, and who had already invested a lot in their marriages, were more likely to have combined their finances (Treas 1993). Consequently, we hypothesize that couples with higher marital quality will report higher levels of sound financial management.

Hypothesis 1 Individuals' T1 marital satisfaction will positively relate to their own and their spouses' T2 sound financial management behaviors. Their T1 marital conflict will negatively relate to their own and their spouses' T2 sound financial management.

\section{Sound Financial Management Maintaining Marital Quality}

Becker's (1981) theory asserted that individuals will marry if the perceived gains from doing so exceed the gains they experience while single. The specific gains to marriage that Becker postulated in his theory (i.e., the exchange of sexcomplimentary labor) are much less salient today than they were earlier in the twentieth century (Lundberg et al. 2016). However, only $29 \%$ of adults in the U.S. population in 2016 had never married (United States Census Bureau 2016). Thus, the gains to marriage likely still exist even if they have changed form. Contemporary gains to marriage in the United States may include financial stability.

One theory, termed the financial expectations and family formation theory, suggests that individuals will not marry 
unless they are economically stable (Gibson-Davis 2009). By delaying marriage until they are economically stable they have a greater assurance that their marriage is more likely to be economically stable (Gibson-Davis 2009). Multiple qualitative studies have indicated that cohabiting couples and single parents would marry if they were more finically stable (Gibson-Davis et al. 2005; Smock et al. 2005). Quantitative research has also verified these findings (e.g., Gibson-Davis 2009). Further, Schneider (2011) found that differences in asset ownership account for much of the racial gap in marriage rates.

Because economic stability predicts the initiation of marriage, couples likely expect to maintain economic stability during the marriage. That is, maintained economic stability might be one of the gains to marriage. In a nationally representative study, couples with higher levels of financial assets were less likely to divorce over time than couples with lower levels of assets (Dew 2009). Further, higher consumerdebt levels were associated with increases in marital conflict levels (Gudmunson et al. 2007), and satisfaction with one's finances was correlated with happiness in one's relationship (Archuleta et al. 2013). By practicing sound financial management behavior, then, couples could be able to better realize and maintain gains to marriage. As couples practice sound financial management behavior and realize the gain of continued financial stability in their marriage, they may be more likely to report having a quality marriage.

Hypothesis 2a Individuals' T2 sound financial management behaviors will positively relate to their own and their spouses' T3 marital satisfaction and negatively relate to their own and their spouses' T3 future marital conflict.

\section{Economic Pressure as a Mediator}

If sound financial management behaviors predict relationship satisfaction, the family stress model suggests a potential mediator. This model originates from research of the U.S. Great Depression, the U.S. 1980s Midwest Farm Crisis, and family stress theory (Liker and Elder 1983; Conger et al. 1990). It suggests that economic hardship (losing a job, cutting back on expenses, etc.) is positively related to feelings of economic pressure (Conger et al. 1990). Feelings of economic pressure include "the emotional, cognitive, and behavioral responses of family members experiencing difficulties in making family resources meet family needs" (Lorenz et al. 1991, p. 376). Economic pressure increases couples' emotional distress, which predicts greater conflict and decreased relationship satisfaction (Conger and Conger 2008; Dew and Xiao 2013).

According to the family stress model, economic hardship and events are precursors to feelings of economic pressure. Much of the existing research emphasizes uncontrollable economic events like recession, job loss, or illness. However, we hypothesize that individuals' financial behaviors also contribute to a couples' feelings of economic pressure. That is, sound financial management will reduce couples' feelings of economic pressure, thus decreasing marital distress. Consistent with this hypothesis, Dew (2007) found that consumer debt was both directly and indirectly related to relationship outcomes via feelings of economic pressure.

On the other hand, asset accumulation and consistent saving makes it easier for couples to meet financial needs and reduce feelings of economic pressure (Dew 2007; Xiao and Anderson 1997). Rhoades et al. (2010) found that partners who invest in the relationship by sharing debt, saving, or sharing assets were more likely to feel happier in the relationship. These studies suggest that sound financial management influences couples' feelings of economic pressure.

Hypothesis $\mathbf{2 b}$ Individuals' feelings of economic pressure will mediate the association between their own and their spouses' sound financial management behaviors and their own and their spouses' marital quality.

\section{Gender, Financial Management, and Marital Quality}

Our final hypothesis concerns gender-specifically whether wives' or husbands' financial behaviors will be more salient to marital quality. This question is relevant because we test partner, as well as actor, effects. That is, we test whether wives' financial behaviors influence husbands' marital quality and vice-versa.

Although few scholars have investigated this area directly, some studies suggest that wives' financial behaviors and their responses to financial issues might matter more than husbands'. For example, in a quantitative study that used dyadic data, husbands' perceptions of the way wives spent money were a stronger predictor of financial conflict than the wives' perceptions of the way husbands spent money (Britt et al. 2017). Further in a longitudinal dyadic study, the association between financial assets, debt, and divorce was mediated by wives' characteristics, but not husbands (Dew 2007, 2009). Thus, we hypothesize that wives' partner effects of sound financial management behavior will be stronger than husbands'.

Hypothesis 3 Partner effects from wives' T2 sound financial management to husbands' feelings of $\mathrm{T} 3$ economic pressure and/or marital quality will be stronger than partner effects from husbands to wives. 


\section{Method}

\section{Data and Sample}

We drew data for this study from the Flourishing Families project (Day et al. 2017). The Flourishing Families project was a community-level sample. Participants were recruited from a large northwestern city in the United States. Data collectors contacted families in census tracts that represented the economic and race/ethnic composition of the city. To be eligible for the Flourishing Families project, a household had to have a child between the ages of 10 and 14 and live in one of the selected census tracts. No other eligibility requirements existed.

The researchers randomly selected families in these tracts using information from a survey research database. The response rate was $61 \%$ of those households that were eligible. Because the survey research database contained fewer families with low SES characteristics, the research team also used convenience sampling techniques (e.g., fliers) to add more low-SES families to the study. Families first participated in the Flourishing Families study in 2007. They participated in follow-up studies on an annual basis until 2017, which was the last wave of the study. For the survey waves we used in this study, participants were given $\$ 100$ (U.S.) for each wave they completed. Data was obtained from the main participant, his or her spouse or partner, and the subject child. Thus, our marriage data is dyadic.

The financial variables we used in this study were not added to the Flourishing Families project until the third wave of data collection and continued only through the fifth wave. Therefore, for the purposes of this study, Wave 3 of the Flourishing Families Project is "Time 1" (T1), Wave 4 is "Time 2" (T2), and Wave 5 is "Time 3" (T3).

To be in our study, participants had to be married at T1. We required participants to be coupled because we wanted to analyze dyads. Further, our analytic technique-the Actor-Partner Interdependence Model (APIM)—requires dyadic data (Kenny et al. 2006). We made the marital restriction because the legal status of couples' finances differs between married and cohabiting couples in most states. This difference likely changes some of the incentives in the economic theory we used, with the result that married and cohabiting couples might feel and behave differently vis-à-vis family financial issues (e.g., Brown et al. 2014; DeLeire and Kalil 2005). The complete data contained only 47 cohabiting couples prior to our application of the marital restriction.

We also restricted participation in this study to those married couples who stayed together from the beginning of the project (i.e., W1) through at least Wave 5.
The reason we used this restriction is that the Flourishing Families project followed only those participants over time who had participated in Wave 1. Thus, for example, if a couple divorced and both former spouses remarried, Flourishing Families would survey the two original (nowex) spouses and not the two new spouses. But we would not be able to use this divorced couple's data because the two ex-spouses would no longer be a dyad. Furthermore, participants and their spouses had to participate in every wave. There were some participants/spouses who would not participate in one of the waves, but then participate in later waves. Because we did not want to use missing data techniques for an entire waves' worth of data, if a participant or a spouse was not present in one of the waves, we deleted that couple.

Finally, because of our hypothesis regarding gender, we used only heterosexual couples in this study. Six gay and lesbian couples met all of the other inclusion criteria for this particular study. However, few scholars have examined financial management within same-sex couples. A qualitative study that examined financial management among gay/ lesbian couples found that almost all of them regarded longterm financial interdependence as problematic (Burns et al. 2008). This suggests that financial norms may differ across heterosexual and homosexual couples. Furthermore, at the time of the beginning of the Fragile Families study, samesex marriage was not legal in the location where participants lived. As already indicated, the legal status likely impacts some of the incentives in the economic theory we used. Our inclusion criteria yielded a sample of 279 couples.

Restricting the data to only those who stayed together for the first five years of the study likely contributed to selection bias in favor of more stable unions. However, the number of dyads who were lost to divorce was relatively small (35 dyads, or $9.4 \%$ of the original sample).

\section{Measures}

\section{Sound Financial Management Behaviors}

We measured sound financial management behaviors using a six-item scale. The items asked participants about their perceptions of their financial behaviors as a couple (e.g., "We spent more than we earned," "We paid our bills on time"). Responses ranged from 1 (never engaged in the behavior) to 5 (almost always engaged in the behavior). We reverse coded some of the items so that higher scale scores represented higher levels of sound financial management behavior. We then took an average of the six items to create the scale.

Although participants reported their financial behavior on a household level, there was some variation within the dyad. For example, wives' and husbands' sound financial 
behavior reports had a correlation of $r=0.76(p<0.01)$. T1 Cronbach's alpha was 0.76 for wives and 0.75 for husbands. T2 Cronbach's alpha was 0.76 for wives and 0.74 for husbands. Finally, T3 Cronbach's alpha was 0.79 for wives and 0.77 for husbands.

\section{Marital Satisfaction}

We measured feelings of relationship satisfaction using the five items from the Quality Marriage Index (Norton 1983). Participants rated their level of disagreement or agreement with statements such as "Our relationship is strong" and "My relationship with my partner makes me happy." Responses ranged from 1 (very strongly disagree) to 5 (very strongly agree). We took a mean of the scores to create the variables. The higher the score, the greater the relationship satisfaction was. T1 Cronbach's alpha was 0.98 for wives and 0.97 for husbands. T2 and T3 Cronbach's alphas were 0.97 for both husbands and wives.

\section{Marital Conflict Frequency}

We measured relationship conflict frequency by taking the mean of eight items that measured how often couples fought about different marital domains. These domains included money, communication, rearing children, sex, in-laws, roles, relationship power, and alcohol or drug use. The response set ranged from 1 (never) to 4 (often). The higher the mean score, the more frequent the conflict. Together, these variables had acceptable levels of reliability. T1 Cronbach's alpha was 0.70 for wives and 0.74 for husbands. T2 Cronbach's alpha was 0.73 for wives and 0.77 for husbands. T3 Cronbach's alpha was 0.76 for wives and 0.75 for husbands.

\section{Economic Pressure}

We used four items that assessed participants' feelings of economic pressure to assess the construct. For example, participants offered their level of disagreement or agreement with statements such as "I have trouble sleeping because of my financial problems" and "I do not know how I will be able to support myself in the next year." We took the mean of these four items to create the variable. T2 Cronbach's alpha was 0.87 for wives and 0.83 for husbands. T3 Cronbach's alpha was 0.83 for wives and 0.85 for husbands.

\section{Control Covariates}

We also had control covariates. We used the Time 1 levels of these variables in the analyses. Participants reported their total household income on a 12-point scale that ranged from 1 (under $\$ 20,000$ per year) to 12 (\$150,000 or more per year) (these numbers were in U.S. dollars). If a husband's and wife's scores differed from each other, we used the higher of the two scores. Participants reported the number of individuals who lived in the household. Participants also reported their race or ethnicity. Because $82 \%$ of the wives and $87 \%$ of the husbands reported that they were White, non-Hispanic, we used only one dummy variable for race and ethnicity. Participants reported their own level of educational attainment. We coded these into two dummy variables: high school or lower and a four-year college degree or higher. The category of having "some college" or an associate degree was the omitted category. Participants reported their relationship duration in years. Finally, we should note that we controlled for initial levels of the outcome variables in the model. For example, we regressed T2 sound financial management behavior on $\mathrm{T} 1$ levels and $\mathrm{T} 3$ marital satisfaction on $\mathrm{T} 2$ levels.

\section{Analysis}

We used the APIM (Kenny et al. 2006) within a path model framework to assess the model (see Fig. 1). In APIM, participants' variables are regressed on their own as well as their partners' variables. This allowed us to examine whether one's own attitudes and behaviors have a differential influence from that of one's partner as some previous studies on financial issues in relationships have suggested. In the APIM, when one spouses' independent variable predicts their own dependent variable, that is termed an "actor effect" (Kenny et al. 2006). When one spouses' independent variable predicts the other spouses' dependent variable that is a "partner effect". We used path models rather than structural equation models because the number of couples in the data $(n=279)$ was not enough to conduct a structural equation model (Kline 2016).

The path models also used residualized gain score methods in the APIM. That is, we regressed the values of the outcome variables on their previous wave values (not shown in Fig. 1). For example we regressed wives' T2 sound financial management behavior on T1 levels of sound financial management behavior and the other independent variables. This allowed us to examine the effect of a variable on the change in the dependent variable over time. For example by regressing wives' $\mathrm{T} 2$ sound financial management behavior on their T1 levels of sound financial management behavior and on $\mathrm{T} 1$ relationship satisfaction, we obtained the association between wives' $\mathrm{T} 1$ relationship satisfaction and the change in their sound financial behaviors from $\mathrm{T} 1$ to $\mathrm{T} 2$ (i.e., "net of," or "controlling for" $\mathrm{T} 1$ sound financial management).

We have a number of data issues that we need to address. First, we ran our analyses in Mplus 8.1. Second, to handle missing data, we estimated the models using Full Information Maximum Likelihood (FIML). FIML is a common way of dealing with missing data and provides estimates 
similar to those provided by Multiple Imputation (Johnson and Young 2011). Third, because our data were dyadic, we correlated wives' and husbands' error structure in the model so that the standard errors were not deflated. Fourth, we assessed model fit using the CFI, RMSEA, and SRMR indices. Fifth, we regressed each of the endogenous variables on all of the control covariates.

The last analytic issue is that we measured the magnitude and significance of the indirect effects using bootstrapping. Bootstrapping is an iterative process that takes random draws of the sample and can be used to make repeated estimates of the size and confidence interval (i.e., 95\% CI) of the indirect effects (Hayes 2009). These estimates are then synthesized. If " 0 " is not within the $95 \%$ confidence interval of any given indirect effect, we consider that evidence that that particular indirect effect is statistically significant.

\section{Results}

\section{Descriptive Statistics}

Table 1 contains the descriptive statistics. The mean of sound financial management behaviors for wives was 3.98 at T1 and 3.92 at T2. For husbands, these two means were 3.98 and 3.92, respectively. The means of relationship satisfaction for wives were 4.97 at $\mathrm{T} 1,4.84$ at $\mathrm{T} 2$, and 4.81 at T3. For husbands, these means were 4.98, 4.93, and 4.87, respectively. The means of relationship conflict for wives were 2.35 (T1), 2.36 (T2), and 2.39 (T3), whereas for husbands they were 2.35 (T1), 2.37 (T2), and 2.35 (T3). The means of feelings of economic pressure were 2.10 (T2) and 2.04 (T3) for wives. For husbands those means were 2.07 and 1.98, respectively. The means and proportions for the control covariates are also located in Table 1.

The trends evident in the descriptive statistics were interesting. Sound financial management means declined over time, as did relationship satisfaction means, whereas the relationship conflict means rose for wives, but were stable for husbands. Further, feelings of economic pressure decreased over time. All of these changes were slight, however.

\section{Results from the Path Model}

The results from the path model are shown in both Table 2 and Fig. 2. Model fit was good with a CFI statistic of 0.98 , a RMSEA score of 0.04 and a $S R M R$ score of 0.02 . The $R^{2}$ values ranged from $0.45-0.67$.

Hypothesis 1 suggested that $\mathrm{T} 1$ satisfaction and conflict would predict participants' $\mathrm{T} 2$ sound financial management behaviors. We found little support for Hypothesis 1. The only related finding was that husbands' own T1 marital satisfaction was positively associated with their own $\mathrm{T} 2$ sound financial management behaviors $(b=0.08, p<0.05)$. T1 marital conflict was unrelated to T2 sound financial management behaviors, however. The $R^{2}$ for wives' T2 sound financial management behavior was 0.67 , and for husbands

Table 1 Descriptive statistics ( $\mathrm{n}=279$ married heterosexual couples)

\begin{tabular}{|c|c|c|c|c|c|c|}
\hline & \multicolumn{3}{|l|}{ Wives } & \multicolumn{3}{|c|}{ Husbands } \\
\hline & $M$ or $\%$ & SD & Min-Max & $M$ or $\%$ & SD & Min-Max \\
\hline $\mathrm{T} 1$ sound financial management behavior & 3.98 & .76 & $2-5$ & 3.98 & .71 & $1.5-5$ \\
\hline T1 marital satisfaction & 4.97 & 1.09 & $1-6$ & 4.98 & 1.00 & $1-6$ \\
\hline T1 marital conflict & 2.35 & .47 & $1.13-3.5$ & 2.35 & .52 & $1.13-4$ \\
\hline $\mathrm{T} 2$ sound financial management behavior & 3.92 & .78 & $2.17-5$ & 3.92 & .76 & $1.5-5$ \\
\hline $\mathrm{T} 2$ marital satisfaction & 4.84 & 1.04 & $1-6$ & 4.93 & 1.00 & $1-6$ \\
\hline $\mathrm{T} 2$ marital conflict & 2.36 & .50 & $1-4$ & 2.37 & .54 & $1-4.5$ \\
\hline $\mathrm{T} 2$ feelings of economic pressure & 2.10 & .94 & $1-4.75$ & 2.07 & .86 & $1-4.5$ \\
\hline T3 marital satisfaction & 4.81 & 1.08 & $1-6$ & 4.87 & 1.01 & $1-6$ \\
\hline T3 marital conflict & 2.39 & .54 & $1-4.5$ & 2.35 & .55 & $1-4.29$ \\
\hline T3 feelings of economic pressure & 2.04 & .87 & $1-4.75$ & 1.98 & .87 & $1-4.75$ \\
\hline T1 total household income ${ }^{a}$ & 9.16 & 2.58 & $2-12$ & 9.16 & 2.58 & $2-12$ \\
\hline T1 household size ${ }^{\mathrm{a}}$ & 4.44 & 1.03 & $3-9$ & 4.44 & 1.03 & $3-9$ \\
\hline T1 P white & 82 & & & 87 & & \\
\hline T1 P high school or less & 6 & & & 6 & & \\
\hline $\mathrm{T} 1 \mathrm{P}$ completed "some college" or associate degree ${ }^{\mathrm{b}}$ & 14 & & & 13 & & \\
\hline $\mathrm{T} 1 \mathrm{P} 4$ year degree or better & 70 & & & 71 & & \\
\hline Relationship duration $^{\mathrm{a}}$ & 17.83 & 4.72 & $2-35$ & 17.83 & 4.72 & $2-35$ \\
\hline
\end{tabular}

${ }^{a}$ Variable measured at the couple level. ${ }^{b}$ Omitted variable in the analyses 
Table 2 The indirect association between marital quality and sound financial management behaviors (SFMB)

\begin{tabular}{|c|c|c|c|c|c|c|c|c|c|c|c|c|c|c|c|c|}
\hline & \multicolumn{4}{|c|}{ T2 SFMB } & \multicolumn{4}{|c|}{ T3 Economic pressure } & \multicolumn{4}{|c|}{ T3 Satisfaction } & \multicolumn{4}{|c|}{ T3 Conflict } \\
\hline & \multicolumn{2}{|l|}{ Wives } & \multicolumn{2}{|c|}{ Husbands } & \multicolumn{2}{|c|}{ Wives } & \multicolumn{2}{|c|}{ Husbands } & \multicolumn{2}{|c|}{ Wives } & \multicolumn{2}{|c|}{ Husbands } & \multicolumn{2}{|l|}{ Wives } & \multicolumn{2}{|c|}{ Husbands } \\
\hline & $\mathrm{b}$ & $\mathrm{SE}_{\mathrm{b}}$ & $\mathrm{b}$ & $\mathrm{SE}_{\mathrm{b}}$ & $\mathrm{b}$ & $\mathrm{SE}_{\mathrm{b}}$ & B & $\mathrm{SE}_{\mathrm{b}}$ & $\mathrm{b}$ & $\mathrm{SE}_{\mathrm{b}}$ & $\mathrm{b}$ & $\mathrm{SE}_{\mathrm{b}}$ & $\mathrm{b}$ & $\mathrm{SE}_{\mathrm{b}}$ & $\mathrm{b}$ & $\mathrm{SE}_{\mathrm{b}}$ \\
\hline Intercept & .06 & .47 & .30 & .45 & $1.36^{*}$ & .53 & $1.98 *$ & .45 & $1.10^{*}$ & .52 & .30 & .47 & $.93 * *$ & .28 & $.78 * *$ & .28 \\
\hline T1 W SFMB & $.67 * *$ & .06 & $.27 * *$ & .06 & - & - & - & - & - & - & - & - & - & - & - & - \\
\hline T1 H SFMB & $.20 * *$ & .06 & $.55^{* *}$ & .07 & - & - & - & - & - & - & - & - & - & - & - & - \\
\hline T1 W Satisfaction & .02 & .03 & -.01 & .03 & - & - & - & - & - & - & - & - & - & - & - & - \\
\hline T1 H Satisfaction & .02 & .03 & $.08 *$ & .04 & - & - & - & - & - & - & - & - & - & - & - & - \\
\hline T1 W Conflict & -.01 & .09 & .02 & .08 & - & - & - & - & - & - & - & - & - & - & - & - \\
\hline T1 H Conflict & .03 & .08 & .04 & .08 & - & - & - & - & - & - & - & - & - & - & - & - \\
\hline T2 W Feelings of Economic Pressure & - & - & - & - & $.52 * *$ & .07 & .01 & .08 & - & - & - & - & - & - & - & - \\
\hline T2 H Feelings of Economic Pressure & - & - & - & - & .04 & .07 & $.49 * *$ & .09 & - & - & - & - & - & - & - & - \\
\hline T2 W Satisfaction & - & - & - & - & - & - & - & - & $.52 * *$ & .10 & $.21 * *$ & .06 & - & - & - & - \\
\hline T2 H Satisfaction & - & - & - & - & - & - & - & - & $.27 * *$ & .09 & $.61 * *$ & .09 & - & - & - & - \\
\hline T2 W Conflict & - & - & - & - & - & - & - & - & - & - & - & - & $.68 * *$ & .06 & $.13 * *$ & .05 \\
\hline T2 H Conflict & - & - & - & - & - & - & - & - & - & - & - & - & .06 & .06 & $.64 * *$ & .06 \\
\hline T2 W SFMB & - & - & - & - & .01 & .09 & -.07 & .09 & .11 & .10 & .05 & .07 & $-.10 *$ & .05 & -.03 & .05 \\
\hline T2 H SFMB & - & - & - & - & -.15 & .09 & $-.19^{*}$ & .08 & -.08 & .10 & -.01 & .09 & .04 & .05 & -.04 & .05 \\
\hline T3 W Feelings of Economic Pressure & - & - & - & - & - & - & - & - & -.13 & .08 & -.07 & .07 & $.06 *$ & .03 & .01 & .03 \\
\hline T3 H Feelings of Economic Pressure & - & - & - & - & - & - & - & - & .05 & .09 & -.03 & .05 & -.01 & .04 & $.07 *$ & .03 \\
\hline T1 Total HH Income & -.01 & .01 & $.04 * *$ & .01 & -.01 & .02 & .01 & .02 & .02 & .02 & .04 &. .02 & -.01 & .01 & .01 & .01 \\
\hline T1 Household Size & .01 & .03 & -.03 & .03 & .06 & .04 & .01 & .04 & -.01 & .04 & -.01 & .03 & -.02 & .03 & -.03 & .03 \\
\hline T1 P White & .06 & .08 & -.15 & .09 & -.24 & .14 & -.25 & .14 & -.02 & .11 & .22 & .12 & -.04 & .06 & -.05 & .08 \\
\hline T1 P High School or less & -.09 & .10 & $.24 *$ & .12 & $.40 *$ & .18 & .09 & .16 & -.26 & .28 & .17 & .15 & -.08 & .10 & .01 & .08 \\
\hline T1 P 4 Year degree + & -.03 & .07 & -.01 & .07 & .05 & .11 & $-.30^{*}$ & .12 & .15 & .13 & -.02 & .09 & -.01 & .07 & .09 & .06 \\
\hline Relationship Duration & .01 & .01 & .01 & .06 & .01 & .01 & .01 & .01 & -.02 & .02 & .01 & .01 & -.01 & .01 & -.01 & .01 \\
\hline $\mathrm{R}^{2}$ & .67 & & .68 & & .45 & & .47 & & .52 & & .63 & & .56 & & .62 & \\
\hline
\end{tabular}

Unstandardized coefficients CFI $=.98, \mathrm{RMSEA}=.04, \mathrm{SRMR}=.02$

${ }^{*} p<.05 . * * p<.01$

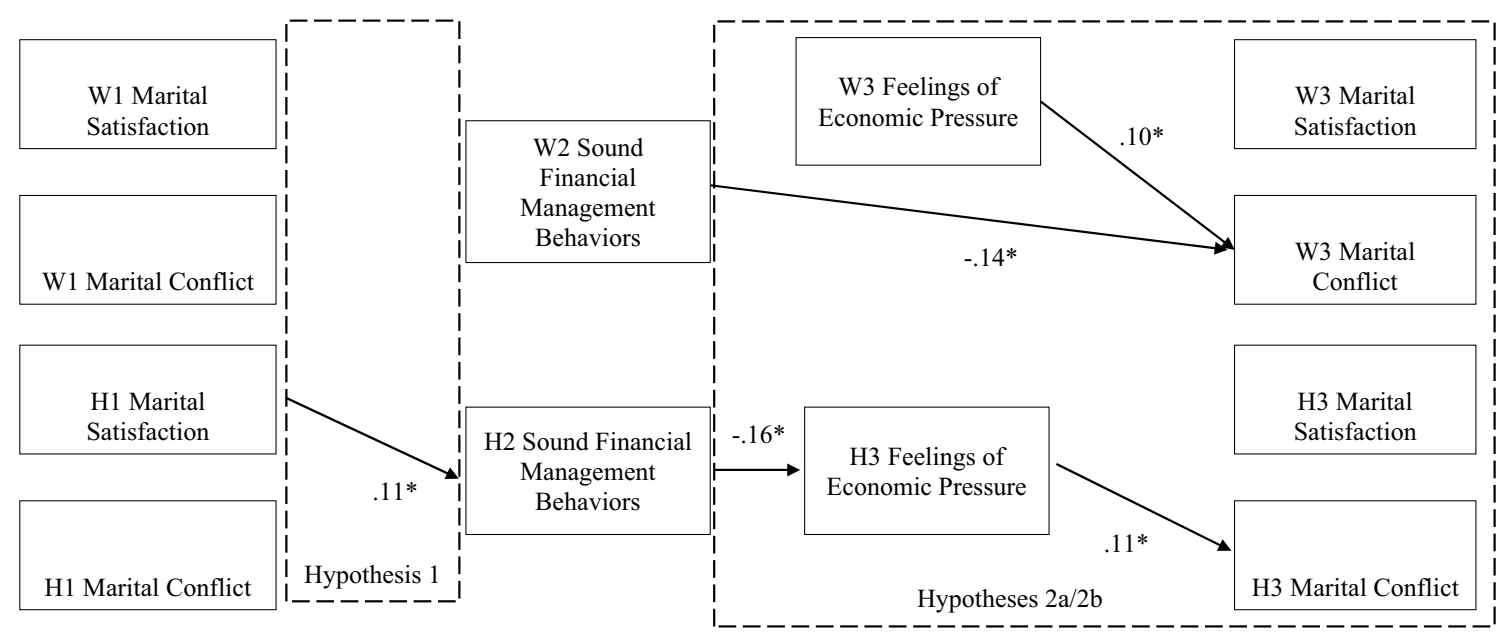

Fig. 2 Statistically Significant Standardized Associations between Relationship Satisfaction and Sound Financial Management. Nonsignificant pathways, control covariates, and error structure not shown for the sake of clarity. T2 sound financial management behaviors regressed on $\mathrm{T} 1$ sound financial management behaviors, $\mathrm{T} 3$ feelings of economic pressure regressed on $\mathrm{T} 2$ levels, and $\mathrm{T} 3$ marital satisfaction/marital conflict regressed on $\mathrm{T} 2$ levels (not shown). $C F I=.98$, $R M S E A=.04, S R M R=.04 . * \mathrm{p}<0.05, * * \mathrm{p}<0.01$ 
it was 0.68 . Figure 2 shows the significant standardized coefficients for the whole model.

Hypothesis $2 \mathrm{a}$ and $2 \mathrm{~b}$ suggested that that participants' $\mathrm{T} 2$ sound financial management behaviors would be indirectly associated with T3 marital quality through the mechanism of T3 feelings of economic pressure. Surprisingly, wives' $\mathrm{T} 2$ reports of sound financial management behaviors were uncorrelated with reports of economic pressure. Husbands' $\mathrm{T} 2$ reports of sound financial management behavior were negatively associated with their own $\mathrm{T} 3$ reports of economic pressure $(b=-0.19 p<0.05)$, as expected. The model explained $45 \%$ of wives' reports of financial pressure and $47 \%$ of husbands' reports. Please see Fig. 2 for the statistically significant coefficients.

As to the second part of the mediation model, a few associations between $\mathrm{T} 3$ economic pressure and $\mathrm{T} 3$ marital conflict emerged. Wives' own T3 economic pressure was positively related to their $\mathrm{T} 3$ reports of conflict $(b=0.06$, $p<0.05)$. The same actor effects emerged for the husbands $(b=0.07, p<0.05)$. The model explained $52 \%$ of wives' and $62 \%$ of husbands' marital satisfaction. Further, it explained $45 \%$ of wives' and $47 \%$ of husbands' marital conflict. Figure 2 shows the standardized coefficients that are statistically significant.

We tested the indirect associations between participants' sound financial management behaviors and marital quality measures using bootstrap estimates of the confidence interval. None of the indirect effects were statistically significant. Although husbands' T2 sound financial management was positively associated with their economic pressure, and their economic pressure was negatively associated with conflict, this indirect effect was not quite statistically significant. The lack of findings in the indirect association analysis fails to support that Hypotheses 2a and 2b. Given our lack of any partner findings, our findings also failed to support Hypothesis 3 .

An unexpected finding emerged. Wives' sound financial management behaviors were directly and negatively associated with their reports of marital conflict $(b=-0.10$, $p<0.05)$. This was the case even with economic pressure in the model.

\section{Discussion}

The purpose of this study was to examine the reciprocal relationship between sound financial management behaviors and marital quality using dyadic, longitudinal data in the United States. Figure 2 shows the results for the complete model. To summarize, husbands' T1 marital satisfaction was associated with increases in their sound financial management behavior between $\mathrm{T} 1$ and $\mathrm{T} 2$. When wives practiced sound financial management at $\mathrm{T} 2$, they reported decreasing marital conflict between $\mathrm{T} 2$ and $\mathrm{T} 3$. In spite of these findings, we were not able to support our longitudinal hypotheses well.

We discuss these findings in light of the theories we reviewed. First, the finding that men with higher satisfaction increased their financial management behaviors supports Becker's (1981) theory that those who are in a satisfying marriage are more willing to invest in their marriage those who are in a less satisfying marriage. This finding supports previous findings that suggested that couples headed toward divorce would start divesting their assets (Finke and Pierce 2006; Zagorsky 2005). The finding from this study, however, has an opposite sign. That is, happy marriages are associated with increasing sound financial management. We also need to acknowledge that this was the only finding that was statistically significant of the four we tested.

Hypotheses $2 \mathrm{a}$ and $2 \mathrm{~b}$ suggested that $\mathrm{T} 2$ sound financial management behaviors would be associated with T3 marital quality but that this association would work through T3 feelings of economic pressure. We did not find support for these hypotheses. Although economic pressure was positively associated with both wives' and husbands' reports of marital conflict, the indirect association was not statistically significant for husbands. Further, sound financial management was not related to lower levels of wives' economic pressure.

These lack of findings may suggest that the family stress model (Conger and Elder 1994), may not apply to our participants. Our sample was relatively affluent and financially stable, for example. Alternatively, previous research has suggested that the closer married couples get to retirement, the less the family stress model applies to them (Dew and Yorgason 2010). Because one of the study requirements was that each family have a child who is tenyears old, the participants were older, on average, than one would get in a random sample of married couples.

Finally, our research aim was to understand the direction of the association between sound financial management and relationship quality. Our model (Figs. 1 and 2) and findings suggest that the association might be bidirectional. That is, marital quality may positively influence later sound financial management behaviors, which then go on to positively influence later marital quality (through the mechanism of sound financial management).

These findings are unique; they are something that studies have not yet demonstrated. This speaks to the interdependent nature between relationship and financial processes. They may mutually reinforce each other. Being in a happy marriage may motivate individuals to delay gratification and manage their money in a sound way. Soundly managing one's finances may then promote marital quality. 


\section{Methodological Explanations for Null Findings}

Although we explained our null findings in terms of the theories, there are also some methodological considerations that may account for these findings. Part of the problem might have been the amount of time, i.e., 1 year, between the waves. Negative financial events and feelings of economic pressure may be more of an acute, rather than chronic, stressor for many married couples. If the negative financial events or feelings of economic pressure are resolved within a year, they may not register vis-àvis future marital quality. Much of Conger et al.'s work was longitudinal, for example, and took place over a three year period, but their participants were facing a protracted regional financial crisis (Conger and Elder 1994).

In hindsight, our model might also have been too robust. We focused on whether sound financial management behavior was associated with change in marital quality and whether marital quality was associated with change in financial management behavior. For example in a post-hoc analysis of the bivariate correlations, T1 marital quality predicted $\mathrm{T} 2$ sound financial management behavior and $\mathrm{T} 3$ sound financial management behavior predicted T3 marital quality (not shown). This was the case for husbands and wives, and both actor and partner effects emerged. This actually contradicts our first methodological self-critique that time between waves might be a problem.

Related to this last point, our small sample likewise limited the study. That is, examining change with a sample under 300 couples might have been too much to ask of the data-particularly given the multi-cause nature of marital quality change. The smaller sample likely limited our statistical power, and we likely have committed a number of Type II errors. For example, we omitted some pathways from Fig. 2 that would have been significant had we used an alpha of $p<0.10$. Higher statistical power might have detected more effects. We were also unable to use structural equation models because of the small sample.

Given the scholarly interest in the interface between financial and relationship issues, future research might do well to reexamine the longitudinal association using data that do not have these problems. Our study might rightly receive some post-hoc critique because of these issues. However, the Flourishing Families data set was the first, and only, that we located that had dyadic data that were longitudinal that also contained the constructs of sound financial management behavior (qua behavior) and marital quality. Thus, we feel that, regardless of only having a few findings emerge, this study contributed to our understanding of the association between financial and relationship issues.

\section{Additional Limitations}

We acknowledge the limitations inherent in our study. The data is from a small, non-representative sample. This study, therefore, lacks external validity vis-à-vis "all" married couples in the United States and in the world. That is, our findings do not necessarily generalize to married couples from rural areas, married couples from different regions of the United States, same-sex married couples, and others. Indeed, our lack of findings may partly be because these couples have been together long enough to have a 10 -year-old child.

Furthermore, T1, T2, and T3 were 2009, 2010, and 2011-years in which the United States was recovering from a severe recession. Thus, because of the macroeconomic issues that these families were facing, our findings might not be representative of more prosperous times. Future research will need to examine our model and findings with more representative surveys.

Another limitation in the study is the selection bias present in both the Flourishing Families data generally and in our sample in particular. To be included in the Flourishing Families data, households had to have a child between the ages of 10 and 14. Consequently, Flourishing Families is biased toward longer-term married couples. Furthermore, to be included in this particular study, participants had to remain married through Wave 5 (i.e., T3) of the Flourishing Families. Thus, the married couples in our study are likely more economically and relationally stable than the average married couple in the United States.

Finally, economic pressure is not the only potential mediator of the association between sound financial management and marital quality. For example, sound financial management behaviors may help couples meet jointly held financial goals (e.g., travel to a foreign country or building a house they have wanted). Accomplishing these goals together might enhance marriage. Consequently, studies might profitably investigate additional mediators of the association between sound financial management and marital quality.

\section{Conclusion}

In spite of these limitations, our study is important. It is the first study we know using longitudinal data to examine both directions of the association between sound financial management behaviors and marital quality. It showed that these two constructs are mutually reinforcing. Furthermore, this study tested this model using dyadic data so that actor and partner effects could be examined. Consequently, our study contributes to the literature on the association between financial issues and marital relations. 
Acknowledgements This research was supported by Wheatley Institution (Research Fellowship).

Funding The Flourishing Families data collection was funded by grants to individual investigators and to the collective project. Donors and funding agencies include the following: School of Family Life Endowment (BYU), Family Studies Center Endowment (BYU), Marjorie Pay Hinckley Endowed Chair (BYU), Mary Lou Fulton Endowed Chair in the Social Sciences (BYU), Mentoring Environment Grant (BYU), LB and LW Smith and Family Foundation, Kreutzkamp Family Foundation, Brent and Cheri Andrus Family Trust, and James W. and Carolyn O. Ritchie Supporting Organization. None of the funding agents had any role in the actual data collection for the Flourishing Families Project. Furthermore, none of the funding agents had any role whatsoever in this particular study. This particular study did not receive any specific grant from funding agencies in the public, commercial, or not-for-profit sectors.

\section{Compliance with Ethical Standards}

Conflict of interest None.

\section{References}

Archuleta, K. L., \& Grable, J. E. (2011). The future of financial planning and counseling: An introduction to financial therapy. In J. E. Grable, K. L. Archuleta, \& R. R. Nazarinia (Eds.), Financial planning and counseling scales (pp. 33-59). New York: Springer.

Archuleta, K. L., Grable, J. E., \& Britt, S. L. (2013). Financial and relationship satisfaction as a function of harsh start-up and shared goals and values. Journal of Financial Counseling and Planning, 24(1), 3-14.

Becker, G. S. (1981). A treatise on the family. Cambridge, MA: Harvard University Press.

Britt, S. L., Hill, E. J., LeBaron, A., Lawson, D. R., \& Bean, R. A. (2017). Tightwads and spenders: Predicting financial conflict in couple relationships. Journal of Financial Planning, 30(5), 36-43.

Brown, S., Durand, R. B., Harris, M. N., \& Weterings, T. (2014). Modelling financial satisfaction across life stages: A latent class approach. Journal of Economic Psychology, 45, 117-121. https ://doi.org/10.1016/j.joep.2014.09.001.

Burns, M., Burgoyne, C., \& Clarke, V. (2008). Financial affairs? Money management in same-sex relationships. The Journal of Socio-Economics, 37, 481-501.

Conger, R. D., \& Conger, K. J. (2008). Understanding the processes through which economic hardship influences families and children. In D. R. Crane \& T. B. Heaton (Eds.), Handbook of poverty and family (pp. 64-81). Thousand Oaks, CA: Sage.

Conger, R. D., \& Elder, G. H. (1994). Families in troubled times. New York City: Aldine de Gruyter.

Conger, R. D., Elder, G. H., Jr., Lorenz, F. O., Conger, K. J., Simons, R. L., Whitbeck, L. B., et al. (1990). Linking economic hardship to marital quality and instability. Journal of Marriage and the Family, 52, 643-656. https://doi.org/10.2307/352931.

Day, R. D., Bean, R., Coyne, S. Dyers, J., Harper, J., \& Walker, L. (2017). Flourishing families project: Survey of family life. [Data file and code book].

DeLeire, T., \& Kalil, A. (2005). How do cohabiting couples with children spend their money? Journal of Marriage and Family, 67, 286-295. https://doi.org/10.1111/j.0022-2445.2005.00116.x.

Dew, J. P. (2016). Revisiting financial issues and marriage. In J. J. Xiao (Ed.), Handbook of consumer finance research (2nd ed., pp. 281-290). New York: Springer.
Dew, J. P. (2009). The gendered meanings of assets for divorce. Journal of Family and Economic Issues, 30, 20-31. https://doi. org/10.1007/s10834-008-9138-3.

Dew, J. P. (2007). Two sides of the same coin? The differing roles of assets and consumer debt in marriage. Journal of Family and Economic Issues, 28, 89-104. https://doi.org/10.1007/s1083 4-006-9051-6.

Dew, J. P., Anderson, B. L., Skogrand, L., \& Chaney, C. (2017). Financial issues in strong African American marriages: A strengthsbased qualitative approach. Family Relations, 66, 287-301. https ://doi.org/10.1111/fare.12248.

Dew, J. P., Dean, L., Duncan, S. F., \& Britt-Lutter, S. (2020). A review of effectiveness evidence in the financial-helping fields. Family Relations, 69, 614-627. https://doi.org/10.1111/fare.12445.

Dew, J. P., \& Xiao, J. J. (2013). Financial declines, financial behaviors, and relationship satisfaction during the recession. Journal of Financial Therapy, 4(1), 1-20. https://doi.org/10.4148/jft. v4i1.1723.

Dew, J. P., \& Yorgason, J. (2010). Economic pressure and marital conflict in retirement-aged couples. Journal of Family Issues, 31, 164-188. https://doi.org/10.1177/0192513X09344168.

Finke, M. S., \& Pierce, N. L. (2006). Precautionary savings behavior of maritally stressed couples. Family and Consumer Sciences Research Journal, 34, 223-240. https://doi.org/10.1177/10777 27 X05283594.

Gibson-Davis, C. M. (2009). Money, marriage, and children: Testing the financial expectations and family formation theory. Journal of Marriage and Family, 71, 146-160. https://doi.org/10.111 1/j.1741-3737.2008.00586.x.

Gibson-Davis, C. M., Edin, K., \& McLanahan, S. (2005). High hopes but even higher expectations: The retreat from marriage among low-income couples. Journal of Marriage and Family, 67, 13011312. https://doi.org/10.1111/j.1741-3737.2005.00218.x.

Glenn, N. D. (1990). Quantitative research on marital quality in the 1980's: A critical review. Journal of Marriage and the Family, 52, 819-831. https://doi.org/10.2307/353304.

Gudmunson, C. G., Beutler, I. F., Israelsen, C. L., McCoy, J. K., \& Hill, E. J. (2007). Linking financial strain to marital instability: Examining the roles of emotional distress and marital interaction. Journal of Family and Economic Issues, 28, 357-376. https://doi. org/10.1007/s10834-007-9074-7.

Hayes, A. F. (2009). Beyond Baron and Kenny: Statistical mediation analysis in the new millennium. Communication Monographs, 76, 408-420. https://doi.org/10.1080/03637750903310360.

Hilgert, M. A., Hogarth, J. M., \& Beverly, S. G. (2003). Household financial management: The connection between knowledge and behavior. Federal Reserve Bulletin, 89, 309-322.

Hogarth, J. M., \& Anguelov, C. E. (2003). Can the poor save? Journal of Financial Counseling and Planning, 14(1), 1-18.

Hong, G.-S., \& Kao, Y. E. (1997). Emergency fund adequacy of Asian Americans. Journal of Family and Economic Issues, 18, 127-145. https://doi.org/10.1023/A:1024920106444.

Jenkins, N. H., Stanley, S. M., Bailey, W. C., \& Markman, H. J. (2002). You paid how much for that? How to win at money without losing at love. San Francisco, CA: Jossey-Bass.

Johnson, D. R., \& Young, R. (2011). Toward best practices in analyzing datasets with missing data: Comparisons and recommendations. Journal of Marriage and Family, 73, 936-945. https://doi.org/10 .1111/j.1741-3737.2011.00861.x.

Kenny, D. A., Kashy, D. A., \& Cook, W. L. (2006). Dyadic data analysis. New York City: Guilford.

Kline, R. B. (2016). Principles and practice of structural equation modeling. New York City: Guilford Press.

Liker, J. K., \& Elder, G. H., Jr. (1930s). Economic hardship and marital relations in the 1930s. American Sociological Review, 48, 343359. https://doi.org/10.2307/2095227. 
Lorenz, F. O., Conger, R. D., Simon, R. L., Whitbeck, L. B., \& Elder, G. H. (1991). Economic pressure and marital quality: An illustration of the method variance problem in the causal modeling of family processes. Journal of Marriage and the Family, 53, 375-388. https://doi.org/10.2307/352906.

Lundberg, S., Pollak, R. A., \& Stearns, J. (2016). Family inequality: Diverging patterns in marriage, cohabitation, and childbearing. Journal of Economic Perspectives, 30, 79-102. https://doi. org/10.1257/jep.30.2.79.

Norton, R. (1983). Measuring marital quality: A critical look at the dependent variable. Journal of Marriage and Family, 45, 141151. https://doi.org/10.2307/351302.

O’Neill, B., Sorhaindo, B., Xiao, J. J., \& Garman, E. T. (2005). Financially distressed consumers: Their financial practices, financial well-being, and health. Journal of Financial Counseling and Planning, 16(1), 73-87.

Rhoades, G. K., Stanley, S. M., \& Markman, H. J. (2010). Should I stay or should I go? Predicting dating relationship stability from four aspects of commitment. Journal of Family Psychology, 24, 543-550. https://doi.org/10.1037/a0021008.

Rothwell, D. W., \& Han, C. K. (2010). Exploring the relationship between assets and family stress among low-income families. Family Relations, 59, 396-407. https://doi.org/10.111 1/j.1741-3729.2010.00611.x.

Schneider, D. (2011). Wealth and the marital divide. American Journal of Sociology, 177, 627-667. https://doi.org/10.1086/661594.

Skogrand, L., Johnson, A. C., Horrocks, A. M., \& DeFrain, J. (2011). Financial management practices of couples with great marriages. Journal of Family and Economic Issues, 32, 27-35. https://doi. org/10.1007/s10834-010-9195-2.

Smock, P. J., Manning, W. D., \& Porter, M. (2005). "Everything's there except money": How money shapes decisions to marry among cohabitors. Journal of Marriage and Family, 67, 680-696. https ://doi.org/10.1111/j.1741-3737.2005.00162.x.

Stanley, S. M., \& Einhorn, L. A. (2007). Hitting pay dire: Comment on "Money: A therapeutic tool for couples therapy". Family Process, 46, 293-299. https://doi.org/10.1111/j.1545-5300.2007.00212.x.

Treas, J. (1993). Money in the bank: Transaction costs and the economic organization of marriage. American Sociological Review, 58, 723-734. https://doi.org/10.2307/2096283.

United States Census Bureau. (2016). America's family and living arrangements: 2016. Table A1. Retrieved from https://www.censu s.gov/data/tables/2016/demo/families/cps-2016.html

Xiao, J. J. (2016). Consumer financial capability and wellbeing. In J. J. Xiao (Ed.), Handbook of consumer finance research (2nd ed., pp. 3-17). Switzerland: Springer International.

Xiao, J. J., \& Anderson, J. G. (1997). Hierarchical financial needs reflected by household financial asset shares. Journal of Family and Economic Issues, 18(4), 333-355.
Zagorsky, J. L. (2005). Marriage and divorce's impact on wealth. Journal of Sociology, 41, 406-424. https://doi.org/10.1177/14407 83305058478.

Zimmerman, K. J., \& Roberts, C. W. (2012). The influence of a financial management course on couples' relationship quality. The Journal of Financial Counseling and Planning, 23(2), 46-54.

Publisher's Note Springer Nature remains neutral with regard to jurisdictional claims in published maps and institutional affiliations.

Jeffrey Dew is an Associate Professor in the School of Family Life at Brigham Young University. He teaches family theory, family finance, and graduate statistics courses. Dr. Dew's research focuses on the "daily life" issue of the association between family resources (i.e., money and time) and relationship quality. Examples of Dr. Dew's recent projects include examining factors that protect couples' marital quality during financial difficulties, and a qualitative strengths-based analysis of how African American couples talk about the role of finances in their marriage. Dr. Dew is a fellow of the Wheatley Institution.

Connor Barham is a Master's student at Brigham Young University studying Marriage and Family Therapy. He is a marriage and family therapist in Utah and values the connection between clinical practice and research. Connor also manages an international Marriage and Family Therapy Practice Research Network (MFT-PRN) and is interested in studying factors that predict relationship satisfaction in nationally representative samples and clinical populations. Connor has presented his research at the National Council of Family Relations (NCFR) and the Association for Financial Counseling and Planning (AFCPE), including findings on the relationships between relationship satisfaction and sound financial management. He has also researches how childhood adversity may be related to relationship formation in therapy.

E. Jeffrey Hill is Camilla Eyring Kimball Professor of Family Life at Brigham Young University where he teaches classes in family finance to about 1000 students each year. His research examines the interface of finances and family life. Dr. Hill obtained a doctorate in Family and Human Development at Utah State University and Masters of Organizational Behavior from the Marriott School of Management at Brigham Young University. He has authored or co-authored seven books and more than 100 scholarly articles and book chapters. 